\title{
April 1936
}

\section{The Journal of}

\section{Laryngology and Otology}

\author{
EDITED BY
}

WALTER HOWARTH

WITH THE ASSISTANCE OF

W. M. MOLLISON

\section{Contents}

The Use of Hearing Aids in the Treatment of Defects of HeARING iN CHILDREN .

I. R. EwING and

A. W. G. Ewing

CLINICAL RECORDS-

A RECORD OF Six CASES OF ORBITAL INFECTION of Nisal Origin, occurring in ChILdREN

R. B. LUMSDEN

A CASE OF LEFT Frontal LoBE Abscess COMPLiCATING Chronic Sinds Infection

A Case of Meningitis complicating MastoidITIS DUE TO THE PNEUMococcus TYPE III

The Spechalist of the Present and of the Future

J. B. Cavenagh

W. H. BRADBEER J. S. Fraser

Socheties' Proceedings-

Royal. Soctety of Medicine-SEction of Otology

\section{ABstracts-}

THE EAR

THE NOSE AND ACcessory SinUsis

THE LARYNX

LKTTER TO THE EDITOR
The Tonsil and Pharynx

THE Gsomhagus AND ENmoscopy MISCELLANEOUS

REVIEWS OF Books

Dr. Atbert Alexander Gray-An Apprectation

OBITUARY-DR. ADOLPH BRONNER

GeNERAT. Notrs

\section{London}

\section{Headley Brothers \\ Io9 Kingsway, W.C.2}





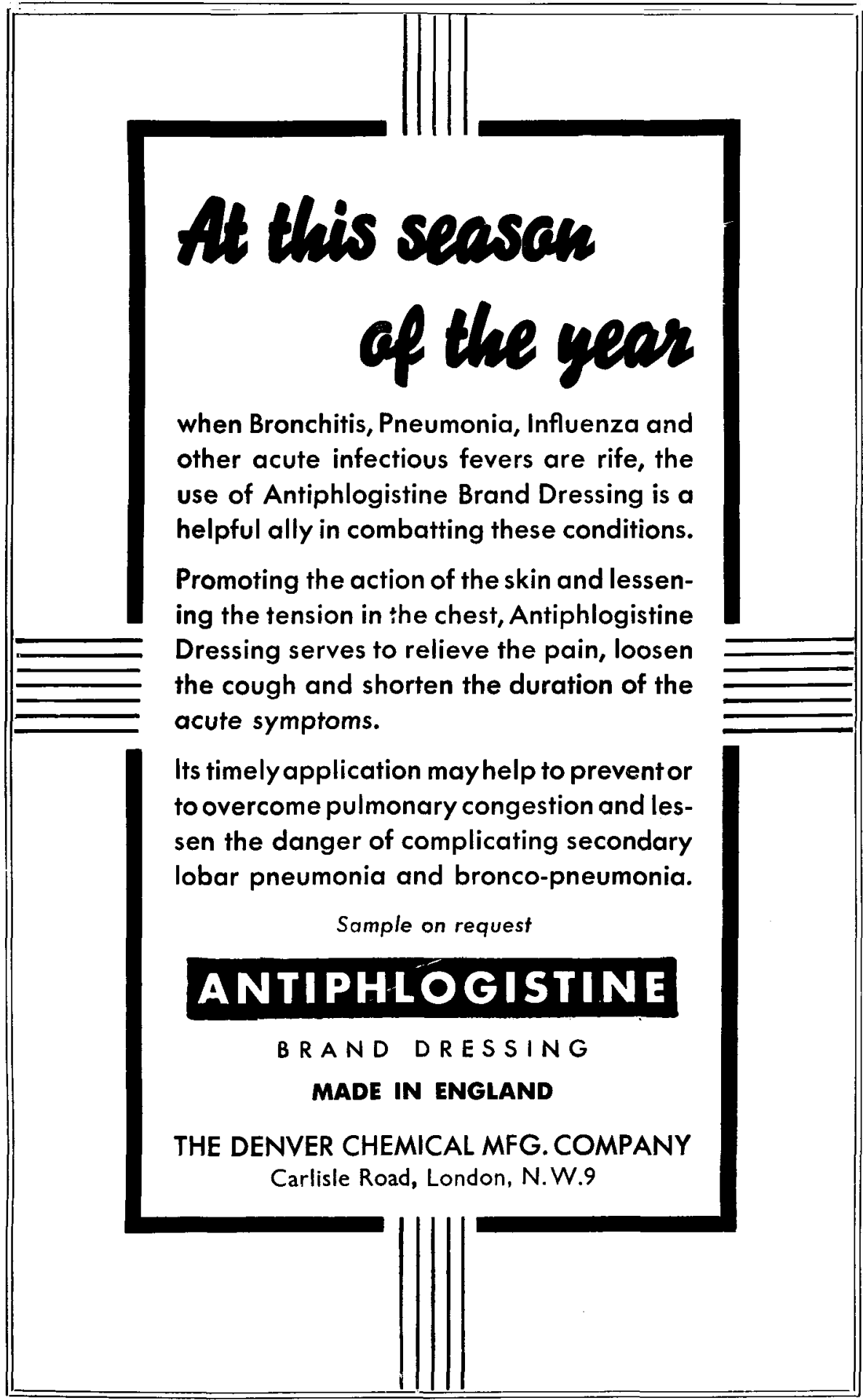

Please mention The Journal of Laryngology when replying to advertisements 


\section{GuY'S SILENT Suction APparatus}

as made for

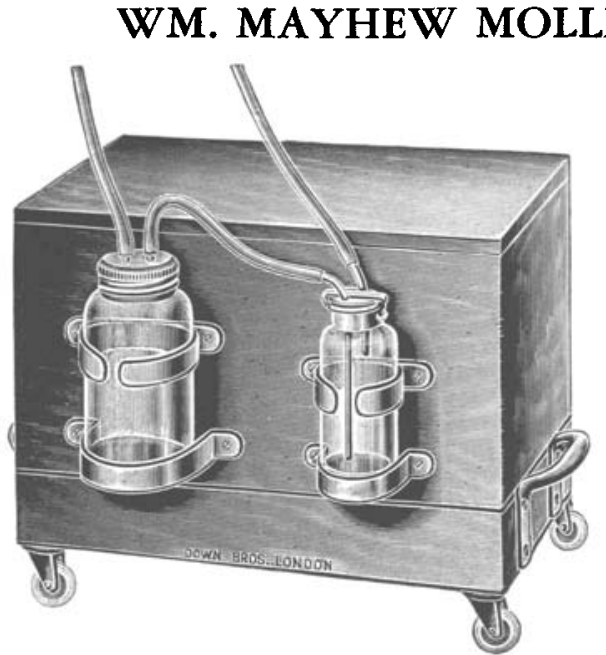

"An efficient silent suction apparatus is essential in many throat investigations and operations and indeed is used for many operations on other parts of the body.

"The above illustration shows an Electric Suction Apparatus which can rightly claim to be more efficient than the apparatus generally in use. The suction is continuous and so powerful that clots of blood and the most tenacious mucus are quickly removed. The apparatus is quiet and can easily be moved about the operation theatre and from one theatre to another. It is possible to use it for intra-tracheal insuftlation at the same time as suction since the pump delivers sixty litres of air per minute. The valves in the cylinder head are strong and specially designed for silence in operation and the sump of the machine carries enough oil for six months' continuous use; this ensutes efficiency with the minimum of attention. The entire unit is mounted in a robust mahogany case which is fitted with four rubber-tyred castors. On the side of the case two large screw necked bottles are mounted. These bottles are the commercial "Kilner" type and can therefore be replaced with the minimum of expense. Blood and other fluids are removed from the operating field by the suction plant and find their way into the big bottle. The second bottle is a safety trap in the unlikely event of the first bottle becoming full at a moment when it is inconvenient to change it.

"There are no resistances to regulate the speed and in order to use the apparatus it is only necessary to connect it to the main electrical supply." The makers are Down Bros., Ltd., London.

\section{DOWN BROS., LTD.}

21 \& 23 ST. THOMAS'S STREET, LONDON, S.E.1

(Opposite Guy's Hospital)

and at 22a CAVENDISH SQUARE, LONDON, W.

Telephone : MAYFAIR 0406

Please mention The Journal of Laryngology when replying to advertisements 


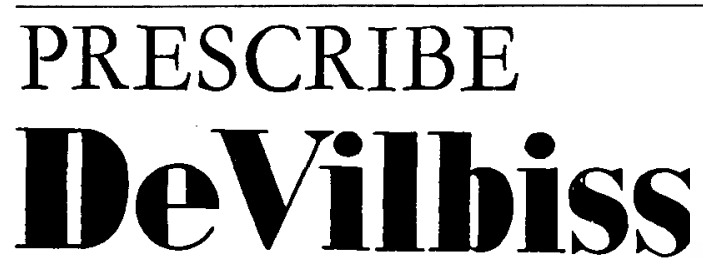

\section{No. 15 ATOMIZER}

For more than 45 years the medical profession has recognized the value of the DeVilbiss No. Is Atomizer for applying sprayed solutions in prescribed self-treatment. The adjustable gold tip permits spraying in any direction, the vented nasal guard prevents excess pressure in the nasal cavities and the atomizer may be sterilized easily and rapidly by boiling or passing the tip through a flame. Dependable and certain in the hands of the patient, the DeVilbiss No. is applies the treatment you want gently and thoroughly - may we suggest that you mark "DeVilbiss Atomizer No. 1s" on your prescription where its use is indicated.

AEROGRAPH Co. Ltd., 43 Holborn Viaduct, London, E.C.I. Sole distributors of DEVILBISS products in the United Kingdom.

Telephone : Holborn 1257 and 1258

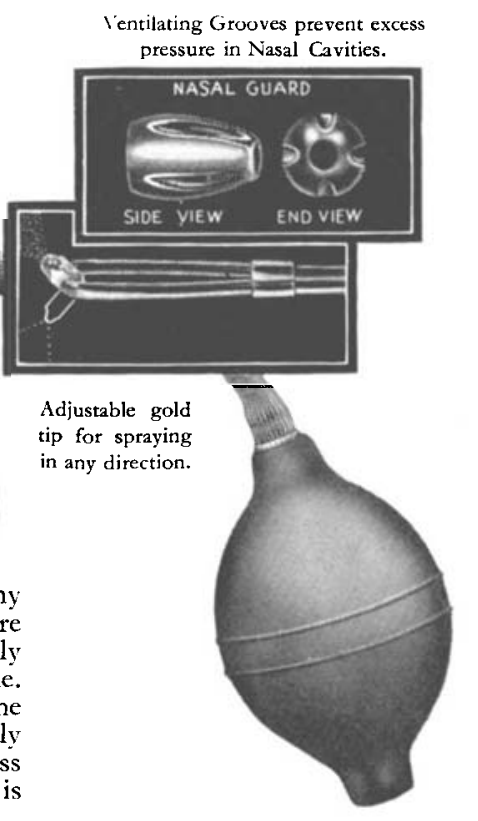

CVS-86

FOURTH EDITION.

FULLY REVISED.

Demy 8vo, 473 pp. 243 Text Illustrations and $2 \mathrm{I}$ plates (of which 8 are in colour). 20s. net, postage $6 d$.

\section{NOSE, THROAT AND EAR}

For Practitioners and Students

Edited by A. LOGAN TURNER, M.D., LL.D., F.R.C.S.E.

Consulting Surgeon, Ear and Throat Department, Royal Infirmary, Edinburgh

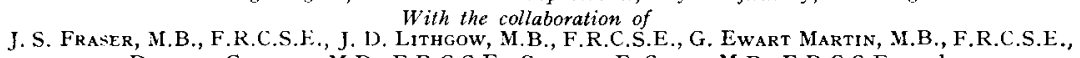
Douglas Grthrie, M.D., F.R.C.S.E., Charles E. Scott, M.B., F.R.C.S.E., and JohN P. Stewart, M.D., F.R.C.S.E.

"There is no other book which includes laryngology and otology with such success. . . . The present edition should surpass the previous issues in popularity."-British Medical Journal.

Bristol: John Wright \& Sons Lid. Net Illustrated Catalogue free. London: Simpkin Marshall Ltd.

For Advertisement space in this Journal and all matters with regard to subscriptions, write to:

HEADLEY BROTHERS, 109 Kingsway, London, W.C.2

Please mention The Journal of Laryngology when replying to advertisements 


\section{THE GOLden SQUARE ThroAT, NOSE AND EAR Hospital Near Piccadilly Circus LONDON, W.I \\ (Gerrard 4058) \\ HONOR ARY MEDICAL ST AHF}

SURGEONS: Mr. Lionel Colledge; Mr. Gilbert Chubb; Mr. F. Cunlife Ormerod; Mr. A. R. Dingley Mr. Gilber. I1. Howells; Mr. J. F. Simpson.

ASSISTANT SURGEONS: Mr. J. C. Hogr; Mr. J. Roydon Peacock; Mr. J. P. Monkhouse.

Physician: Dr. C. E. Lakin.

Neurologist: Dr. L. R. Yealland.

GENERAL SURGEON: Mr. J. B. Hunter. DENTAL SURGEON : Mr. B. Mendleson.

RADIOLOGIST: Dr. Edith Hope.

ANæSTHETISTS : Dr. G. I. Moriarty ; Dr. A. W'. Matthew ; Dr. S. Coffin ; Dr. J. H. T. Challis;

Dr. F. Longhurst: Dr. D. Lewis; Dr. G. Hochschild; Dr. G. Edwards ; Dr. Blair Gould.

The Hospital has 101 Beds for In-patjents and an annual Out-patient attendance of over 50,000.

\section{CLINICAL INSTRUCTION}

Clinical instruction in the Diagnosis and Treatment of Diseases of the Ear, Nose and Throat is given in the Out-patient Department from 2 to 5 p.m. daily, and on Tuesdays and Thursdays from 6 to 9 p.m. also. Major operations are performed every morning and afternoon, except Saturdays, in the In-patient Operating Theatres. Minor operations are performed in the Out-patient Operating Theatre on three mornings a week.

Practitioners and Medical Students are admitted to the practice of the Hospital as Post-Graduates. Clinical Assistants, whose duty it is to assist the staff, are appointed as vacancies occur.

For further information apply to the Dean: GILBERT H. HOWELLS.

In addition to the General Wards, there are Semi-private Wards and I I Ptivate Rooms. The charge for a Private Room is 7 guineas a week, plus a fee for the surgeon.

Further particulars may be obtained from F. P. CARROLL, Secretary-Superintendent.

\section{POLLEN GRAINS}

Their structure, identification and significance in science and medicine.

By R. P. WODEHOUSE, Ph.D.

Scientific Director of the Hayfever Laboratory,

The Arlington Chemical Company.

574 pages, $9 \% 6,123$ illustrations

$36 /-$ net

A general treatment of pollen grains, giving special attention to the kinds which are wind pollinated and cause hayfever or are likely to be found fossilized in sedimentary deposits. The book sets forth and evaluates the characters whereby the pollen grains of different species may be distinguished, and those also which indicate phylogenetic differences and relationships.

The illustrations, original and almost all the work of the author, are a noteworthy feature of the book.

$$
\text { CONTENTS }
$$

Introduction-Pollination and Fertilization-Pollen Grains and Worlds of Different Sizes.

$$
\text { PART I.-General }
$$

Historical Review-Methods of Collecting Pollen in Large Amounts-Preparation of Pollen for Microscopic Examination-Pollen Statistics : A Botanical and Geological Reseatch Method by Prof. G. Frdman-Atmospheric Pollen-Hayfever : Early Spring, Early Summer, Late Summer. Polien Grain Characiers-I. General--II. The Trischistoclastic System.

PART II.-Classification

Master Key-Fossi] Gymnosperms: Living Gymnosperms : Key to the Genera-AngiospermaGlossary-Bibliography-Index.

\section{McGraw-Hill Publishing Company, Ltd. Aldwych House London, W.C.2}

Please mention The Journal of Laryngology when replying to advertisements 


\title{
Mail Your Order Non! \\ PROBLEMS OF THE DEAF
}

\author{
By MAX A. GOLDSTEIN, M.D., F.A.C.S.
}

\author{
610 Pages-273 Illustrations-Leather Bound
}

$\$ 6.00$ Postage prepaid

An unusual, authoritative and comprehensive volume of XIX chapters, covering every phase of work with the Deaf, Deafened and Speech Defective, by an otologist and teacher of 40 years' experience, including :

Chronological History of Deafness-Anatomy and Physiology-Mechanics of Speech-Speech Defects-Cerebral Localization-Hearing 'Tests-Methods of Instruction-The Acoustic Method-Training of Teachers-The Deaf Child--Hardof-Hearing Child-Physician and Deaf Child-Parent of Deaf Child-Deafened Adult-Hearing Aids-Schools for the Deaf-Quacks and Quackeries-Research.

\section{Published by THE LARYNGOSCOPE PRESS}

4574 West Papin Street

ST. LOUIS, MO.

\section{SCULPTURE IN THE LIVING}

\section{Rebuilding the Face and Form by Plastic Surgery}

JACQUES W. MALINIAK, M.D.

lormer Major, Reconstructive Hospitals, Allied Armies, Attending Plastic Surgeon, Sydenbam Hospital, Sew York, N.Y., St. Peter's Hospital, New Brunswick, N.J., L.S.A. etc.

Foreword by WENDEI.L C. PHILLIPS, M.D., former President of the American Medical Association

AMONG OTHER CHAPTERS :

Repairing the Skin, Reconstruction of the Nose, Rebuilding the Mouth and Chin, Deformities about the Eyes, The Malformed Ear, Facial Asymmetries, Legal and Illegal Aspects of Plastic Surgery.

"This book is destined to meet a real need in the medical world." - Wendell C. Philitps, M.D.

"Charmingly written, instructive and authoritative."-N.Y. State JovrNal, OF Medicine.

" "Sculpture in the Living, is the most reliable guide to proper advice and management of the deformed and disfigured."-Solthern Medicinf AND SCRGERY.

$$
203 \text { pages. } \quad \mathrm{3} 34 \text { illustrations. }
$$

\$3.I5 per copy, post paid.

\section{USE THIS ORDER FORM TO-DAY!}

Romaine Pierson Plblishers, Inc., 93 Nassau Street, New York, N.Y., U.S.A. I enclose \$3.I5. Send the book by return mail.

Name

Address

Please mention The Journal of Laryngology when replying to advertisements 


\section{BACK NUMBERS OF THE Journal of Laryngology \& Otology}

Back numbers of most issues of this Journal can be obtained from the Publishers, Headley Brothers, ro9 Kingsway, London, W.C.2. The following, however, are out of print, and no stock is at present available :

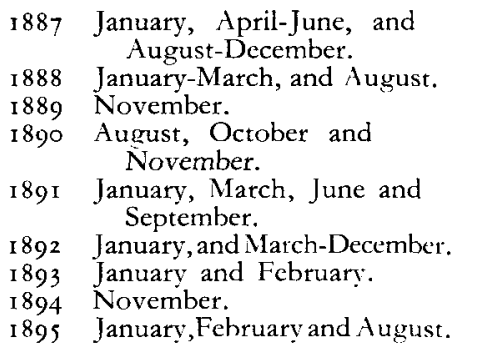

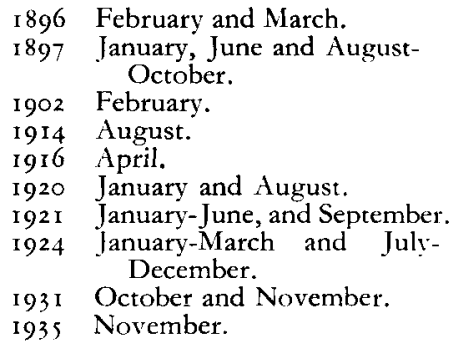

If any subscribers have any of these copies which they do not need, it would be greatly appreciated if they would return them to the Publishers who will refund the full published price.

HEADLEY BROTHERS, Io9 KINGSWAY, LONDON, W.C.2

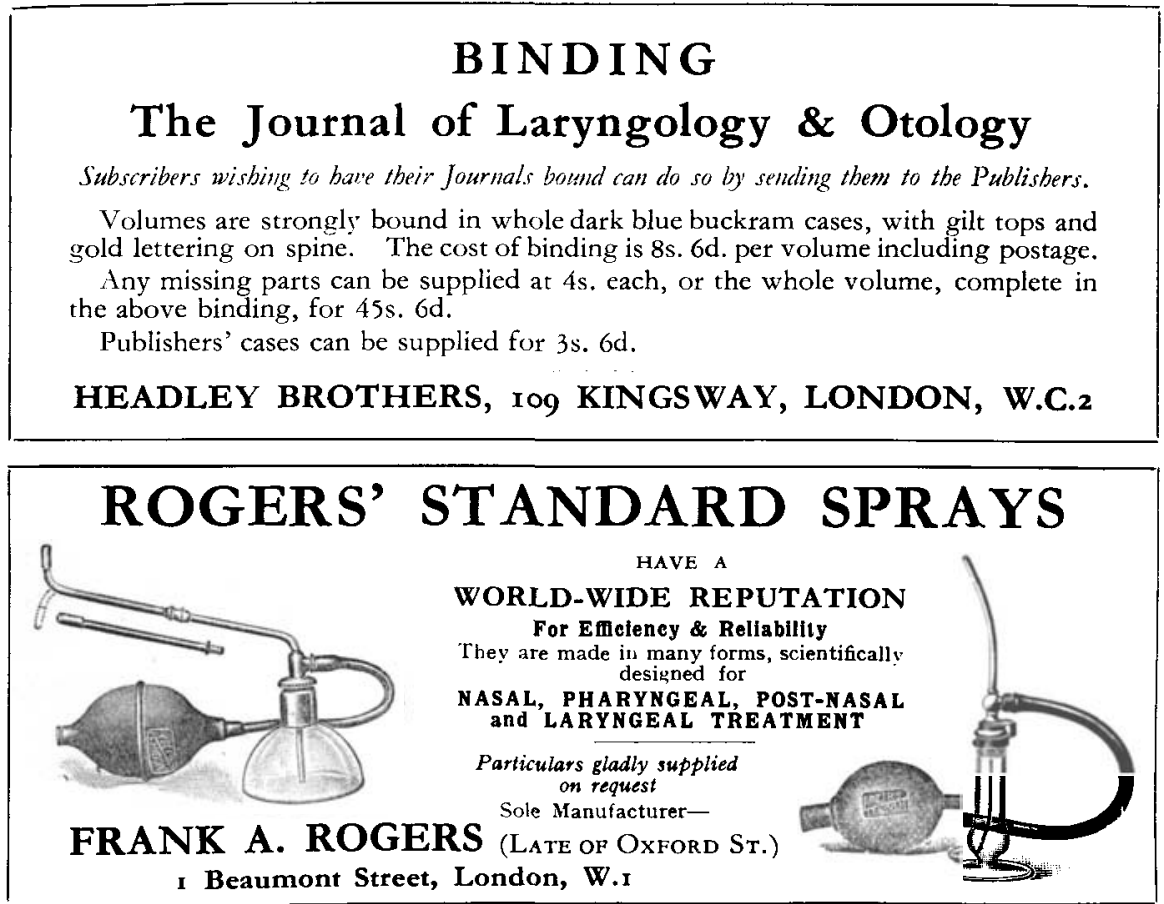

Please mention The Journal of Laryngolugy when replying to advertisements 


\section{The Journal of \\ Laryngology and Otology}

(Founded in 1887 by Morell MackeNzIE and Norris Wor.fendeN)

EDITED BY

WALTER HOWARTH

ASSISTED BY

W. M. MOLLISON

I. Original Articles are accepted on the condition that they have not been published elsewhere.

2. Manuscripts should be typewritten, on one side only of the paper, and well spaced.

3. Galley proofs and engraver's proofs of illustrations are sent to the author. Corrections, which should be kept to a minimum, must be clearly marked and no additional matter added.

4. Orders for reprints should be sent when returning galley proofs, and for this purpose special forms are supplied, on which the price of the reprints is stated.

5. Authors of Original Communications on Oto-Laryngology in other Journals are invited to send a copy, or two reprints, to the Journal of Laryngology. If they are willing, at the same time, to submit their own abstract (in English, French, Italian, or German) it will be welcomed.

6. Editorial Communications may be addressed to ThE Editor, Journal of Laryngolog', c/o HeadLeY Brothers, Io9 Kingsway, London, W.C.2.

7. The Annual Subscription commencing with the January issue is Two Pounds sterling, post free, and is payable in advance.

8. Single copies, both of the present and the previous series, are on sale at Four Shillings each.

9. All Subscriptions, advertising and business communications should be sent to the Publishers, Headley Brothers, I09 Kingsway, London, W.C.2.

\section{United States of America}

Orders for this Journal may be sent either through a local bookseller, or to Messrs. G. E. STeChert \& Co., 3 I-33 East Ioth Street, New York, or direct to the Publishers, Headley Brothers, rog Kingsway, London, W.C.2, England.

Please mention The Journal of Laryngology when replying to advertisements 


\section{CONTENTS}

The Use of Hearing aids in the Treatment of Defects of Hearing in Children. I. R. Ewing and A. W. G. Ewing, Manchester

\section{Clinical Records-}

A Record of Six Cases of Orbital Infection of Nasal Origin, occurring in Children. R. B. Lumsden, Edinburgh

A Case of Left Frontal Lobe Abscess complicating Chronic Sinus Infection. J. B. Cavenagh, Worcester .

A Case of Meningitis complicating Mastoiditis due to the Pneumococcus Type III. W. H. Bradbeer, London

The Specialist of the Present and of the Future. J. S. Fraser, Edinburgh

Societies' Proceedings--

Royal Society of Medicine-Section of Otology

Abstracts-

The Ear • • • • •

An improved apparatus for detecting simulation of unilateral deafness. Exceptionally long latent period of an Otogenic Temporal Lobe Abscess, with a Exceptionally long latent period of an Otogenic Temporal Lobe Abscess, with a
histological study of the Brain Abscess and of the Temporal Bone. B. Kecht : The Otological manifestations of Neurological Disease. D. G. Carruthers.

The Nose and Accessory Sinuses.

$$
\text { - }
$$

Sinusitis, allergy and the common cold. E. C. Sewall; Late changes in the Mucosa of the Frontal Sinuses and Nose in Dogs following Ionization. B. J. McMahon ; Epitheliomata of the Ethmo-maxillary region, their treatment by $\mathrm{X}$-ray Therapy associated with Surgery. Maurice Jacoud.

The Larynx

$$
\text { - }
$$

Tuberculosis of the Larynx requiring Tracheotomy. M. C. Mverson: Tracheotomy for the relief of Laryngeal Obstruction in Children. H. F. Kully:

The Tonsil and Pharynx.

$X$-ray treatment of the Tonsils. H. Loebell ; Meningitis complicating Angina. F. Jennemann; The question of Tonsillotomy : a Clinical and Pathological Study. J. Jeschek; Retothelial Sarcoma. G. Eigler and J. Koch.

Respiratory types of Cancer of the CEsophagus. Dr. Jousseaume.

Miscellaneous

Fracture of the Skull with prolapse of Brain Substance into the External Auditor Meatus. Recovery. N. A. Nikolaew; Some cases of Neurinoma. K. A. Drennowa; Edema of the Larynx occurring in Epidemic Parotitis. Professor Reverchon: Disease of the Hip complicating Otogenic Sepsis. Professor

\section{LetTer TO THE EDITOR}

Reviews of Books

Dr. Albert Alexander Gray-An Appreciation 